\title{
Teacher educators' conception of teaching and learning in teacher education institutions
}

Igwebuike, Thomas B. $\bowtie$

College of Education, Warri, Nigeria (dadaigwebuike@yahoo.com)

Okandeji, Comfort O.

College of Education, Warri, Nigeria (cokandeji@yahoo.com)

Ekwevugbe, Adams O.

College of Physical and Health Education, Mosogar, Nigeria (ekwevugbe_phd@yahoo.com)

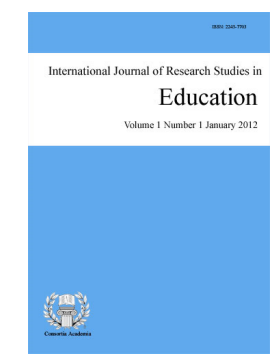

ISSN: 2243-7703 Online ISSN: 2243-7711

OPEN ACCESS

$\begin{array}{lll}\text { Received: } 18 \text { April } 2012 & \text { Revised: } 29 \text { May } 2012 & \text { Accepted: } 10 \text { June } 2012\end{array}$

Available Online: 11 September $2012 \quad$ DOI: $10.5861 /$ ijrse.2012.96

\section{Abstract}

Effectiveness of teaching reflects interplay among a number of teacher-variables prominent among which is the teacher's conceptions of teaching and learning. In educational institutions where teachers are educated, the influence of these conceptions on effectiveness is geometric. This is because teacher educators are teachers of teachers and most teachers teach the way they were taught. Two major conceptions of teaching (traditionalist/transmissive and contemporary/constructivist) have been delineated. The purpose of this study was to determine if a majority of teacher educators in Colleges of Education, Delta State Nigeria have contemporary/constructivist conceptions of teaching, and if teacher variables (qualification, discipline and experience) would influence their conceptions. A customized instrument was administered to 179 teacher educators selected through the use of cluster sampling technique. Results indicated that; a majority of the teacher educators had traditionalist /transmissive conceptions of teaching and learning, qualification and discipline did not influence their conceptions, inexperienced teacher educators had conceptions that were more inclined to contemporary/constructivist conceptions than the experienced teacher educators. Implications of these results for improvement of teacher education programs and for further research have been drawn.

Keywords: conceptions of teaching; constructivist conceptions of teaching; transmissive conceptions of teaching; teacher educators; teacher education 


\section{Teacher educators' conception of teaching and learning in teacher education institutions}

\section{Introduction}

Conceptions of teaching and learning by teachers and teacher educators have been focus of considerable attention by researchers in education for some decades now (Young, 1981; Pope \& Scott 1983, Igwebuike, 1997; 2000; 2009; Igwebuike \& Okandeji, 2009; Bruner, 1996; Entwistle, Skinner, Entwistle, \& Orr, 2000; Samuelowicz \& Bain, 2001; Kane, Sanddretto, \& Heath, 2002; Chan, 2004; Hoy, Davis, \& Pape, 2006; Teo \& Chai, 2008). This attention is energized by the fact that effectiveness of teaching by a teacher depends on some factors prominent among which is his conception of teaching and learning. Consequently some researchers in education have turned their gaze on these conceptions. According to Teo and Chai (2008), studies of this nature provide information needed by teacher educators on issues relating to the design and evaluation of teacher education and professional development programs.

Strands of research evidence, from many of the studies cited above, converge to indicate that there are two major conceptions of teaching. They are the traditional/transmissive and the contemporary/progressivist /constructivist conception. The traditional/transmissive conception, which is more prevalent in classrooms, places much emphasis on teaching as transmission of corpus of knowledge from authoritative sources like teachers and textbooks to students who are passive recipients. The students are assumed to be acolytes who should receive knowledge from teachers unquestioningly. The contemporary/progressivist/constructivist conceptions of teaching are predicated on the principle that it is a process of assisting and guiding the learner during his attempts to construct meanings from series of experiences in his environment. By implication, this conception emphasizes the point that the learner should be actively involved in the process of making sense from myriads of experience in and out of classrooms. Strands of research evidence converge to confirm the efficacy of the contemporary/constructivist conception of teaching when compared with the traditional/transmissive conception (Trumper, 1990, 1991; Asim, 1998; Bajah \& Asim, 2000; Igwebuike, 2000; Chang \& Bell, 2002; Ndioho, 2008).

Despite this confirmation, there is penumbra of uncertainty concerning the application of contemporary/constructivist conception of teaching in the classrooms by teachers and teacher educators. Reacting to this situation, Igwebuike (2009) and Igwebuike and Okandeji (2009) expressed with some trepidation, that predominant traditional/transmissive conception of teaching and its practice by teacher educators will not produce the quality of teaching force necessary to achieve Vision 20-2020 in Nigeria. Igwebuike (2009) amplified the need to revamp curriculum packages for teacher education programs and presented a curriculum development model for achieving this.

As mentioned earlier, conceptions/beliefs influence practice though the relationship between beliefs and practice is complex and difficult to explain (Fang, 1996; Segal, 1998); and teachers' views are eclectic (Igwebuike, 1997; Teo \& Chai, 2008) and highly contextual (Teo \& Chai, 2008). One of the reasons for the difficulty in explaining the relationship according to Teo and Chai (2008) is the measurement of the conceptions about teaching and learning. They contributed to the literature on teachers' beliefs by carrying out a confirmatory factor analysis of the conceptions about Teaching and Learning Questionnaire (CTLQ) using a sample of pre-service teachers. They improved on original 2 - structure of CTLQ by presenting a 5 - structure model which they found to have the best fit.

By implication, the problem of measurement of the conceptions about teaching and learning is reduced. In the Nigerian experience, the literature is mute on the conceptions about teaching and learning held by teacher educators. A study in this direction was carried out to investigate views of teaching and learning held by some teacher educatees (Igwebuike, 1997). This study produced evidence which indicated that the views of teacher 
educatees were eclectic. The result can be explained, in part, by the fact that the instrument used had items which were not subjected to factor analysis which would have guaranteed mutual exclusivity of responses and bolstered its psychometric integrity. It should be pointed out too that this study was carried out on pre-service teachers and not on teacher educators specifically.

Perhaps if the conceptions of teacher educators on teaching and learning are determined, revamping of teacher education programs will be facilitated. It is hoped that the findings will provide enlightenment as regards the quest for ways of making teacher education programs more efficacious. Specifically, the following research hypotheses were tested:

$\mathrm{H}_{0} 1$ : The proportion of teacher educators who have traditionalist/transmissive conceptions of teaching and learning is not significantly greater than 0.5 .

$\mathrm{H}_{0}$ 2: There is no significant difference in conception of teaching and learning between qualified and non-qualified teacher educators.

$\mathrm{H}_{0} 3$ : There is no significant difference in conception of teaching and learning between teacher educators in science and technology related disciplines and their counterparts in arts and social sciences related disciplines.

$\mathrm{H}_{0} 4$ : There is no significant difference in conceptions of teaching and learning between experienced and inexperienced teacher educators.

A qualified teacher educator is one that has at least a bachelors' degree in education, while an experienced teacher educator is the one that has participated as a lecturer in teacher education for at least 20 years.

\section{Method}

\subsection{Subjects}

Two hundred and forty teacher educators selected from 2 randomly selected Colleges out of 4 Colleges of Education in Delta State, Nigeria constituted the subjects. The subjects were selected using cluster sampling technique and the clusters were qualification, teaching experience and discipline. The distribution of the subjects into these variables is shown in Table 1.

\subsection{Instrument}

Data on teacher educators' conception of teaching were collected using Conceptions of Teaching and Learning Questionnaire (CTLQ) which was designed by Chan (2001). It is a two-factor, 30-item questionnaire designed to measure the Traditionalist Conception and Constructivist Conception of teaching and learning. It consists of an 18 - item traditionalist conception (TT) and a 12 - item constructivist conception (CT).

The response options in the original version follow a 5 - point Likert type format ranging from 1 (Strongly Disagree) to 5 (Strongly Agree). It yields a total score that ranges between 30 and 150. It was subjected to factor analysis and other processes that would help establish its psychometric integrity. The two factors accounted for $28.92 \%$ of the variance in the scores with factor loadings of 0.30 and higher. The Cronbach alpha for the traditionalist conception and constructivist conception are both 0.84 .

Teo and Chai (2008) subjected the CTLO to a more rigorous confirmatory factor analysis. The results of their study do not support a two-factor solution provided by Chan (2001), but indicated a 5-factor model. While the Constructivist Conceptions loaded into one factor, the Traditionalist Conceptions loaded on four factors. The five factors are: Constructivist Teaching (12 items), Teacher-centered Teaching (7 items), Directive teaching (5 items), Transmissive Teaching (4 items), and Rote Teaching (2 items). 
Igwebuike, T. B., Okandeji, C. O., \& Ekwevugbe, A. O.

Acknowledgeably, Teo and Chai (2008) have rigorously established the factorial purity of the CTLQ. By implication, analysis of data from CTLQ should take cognizance of these distinct factors. But this study is concerned about composite analysis of the conceptions of teaching and learning bifurcated principally into Traditionalist and Constructivist types. Secondly, the instrument was modified by making the response options to range from 1 (Strongly Disagree) to 4 (Strongly Agree). This gives total scores that range from 30 to 120). The samples used by Chan (2001) and Teo and Chai (2008) are different in some ways (educational level, culture, language etc). Consequently, Cronbach alpha model was used to determine the reliability level of the instrument compositely using a different sample of 40 teacher educators. This yielded a value of 0.793 which is considered reasonable for this type of study. For the purpose of the present study, a teacher educator is said to have conceptions of teaching and learning that are inclined towards constructivist epistemology when he or she scores 80 and above.

\subsection{Procedure}

CTLQ was administered to the subjects by the researchers. The subjects responded and returned the questionnaire to the researchers immediately. This guaranteed maximum retrieval. The responses were scored as described under "Instrument" in the previous section. Frequency counts and percentages of responses under each response option were determined. The first hypothesis was tested using the Z-test for a single proportion and an alpha level of 0.05. A $2 \times 2 \times 2$ ANOVA was carried out to test the remaining 3 hypotheses and for testing if there would be significant interaction of variables. This was observed at the 0.05 alpha levels.

\section{Findings}

The first hypothesis states that the proportion of teacher educators who have constructivist conception of teaching and learning is not significantly greater than 0.5 . To test this hypothesis, the Z-test for a single proportion was used. Out of 179 teacher educators that formed the subjects of this study, 116 had traditionalist/transmissive conception. The value of $\mathrm{Z}$ ratio calculated (observed) was 3.75 while the critical $\mathrm{Z}$ at the 0.05 level of significance is 1.96 . The observed $\mathrm{Z}$ is more than the critical value and by implication, the observed proportion of teacher educators who have traditionalist/transmissive conception of teaching and learning significantly deviates from what would have been obtained by chance $(p<0.05)$. The null hypothesis tested here was therefore rejected. This means that a majority of the teacher educators have traditionalist/transmissive conception of teaching and learning.

Hypothesis 2 states that there is no significant difference in conception of teaching and learning between qualified and non-qualified teacher educators. Table 3 indicates that there is no significant difference in conception of teaching and learning between qualified and unqualified teacher educators $\left[\mathrm{F}_{(1,178)}=1.914, p>\right.$ 0.05]. The hypothesis of no difference in conception between qualified and non-qualified teacher educators was therefore not rejected.

Hypothesis 3 states that there is no significant difference in conception of teaching and learning between teacher educators in science and technology related disciplines and their counterparts in arts and social sciences. Table 3 indicates that there is no significant difference in conception of teaching and learning between the two groups $\left[\mathrm{F}_{(1,178)}=0.314, p>0.05\right]$. Hypothesis 3 was therefore not rejected.

Hypothesis 4 states that there is no significant difference in conception of teaching and learning between experienced and inexperienced teacher educators. Data from table 3 indicate that there is significant difference in conception of teaching and learning between the two groups $\left[\mathrm{F}_{(1,178)}=4.55, p<0.05\right]$. This hypothesis was therefore rejected. This means that inexperienced teacher educators with higher group mean had conception of teaching and learning that is more inclined to constructivism than experienced teacher educators. 
Teacher educators' conception of teaching and learning in teacher education institutions

Table 1

Means and Standard Deviations (SD) of scores on perception by teacher educators

\begin{tabular}{|c|c|c|c|c|c|c|}
\hline \multirow{2}{*}{ Items } & \multicolumn{2}{|c|}{ Discipline } & \multicolumn{2}{|c|}{ Qualification } & \multicolumn{2}{|c|}{ Experience } \\
\hline & $* A \& S$ & $* * \mathrm{~S} \& \mathrm{~T}$ & Qualified & Non-Qualified & Experienced & Inexperienced \\
\hline$N$ & 93.00 & 86.00 & 94.00 & 85.00 & 98.00 & 81.00 \\
\hline Mean & 94.12 & 94.27 & 95.07 & 93.29 & 92.64 & 96.15 \\
\hline$S D$ & 9.60 & 8.88 & 9.65 & 8.70 & 8.86 & 9.36 \\
\hline
\end{tabular}

Table 2

Summary of the $2 \times 2 \times 2$ ANOVA on the scores on conceptions

\begin{tabular}{|c|c|c|c|c|}
\hline Source & SS & $D f$ & MS & $F$ \\
\hline \multicolumn{5}{|l|}{ Main effects } \\
\hline Experience & 366.917 & 1 & 366.917 & $4.545^{*}$ \\
\hline Discipline & 25.330 & 1 & 25.330 & .314 \\
\hline Qualification & 154.491 & 1 & 154.491 & 1.914 \\
\hline \multicolumn{5}{|l|}{$2-$ way Interaction } \\
\hline Exp. $x$ Discipline & 5.789 & 1 & 5.789 & 0.072 \\
\hline Exp. x Qualification & 613.171 & 1 & 613.171 & $7.596 * *$ \\
\hline Discipline $\mathrm{x}$ Qualification & 0.014 & 1 & 0.014 & 0.000 \\
\hline 3-way Interaction & & & & \\
\hline Exp. x Disc. $x$ Qualification & 0.012 & 1 & 0.012 & 0.000 \\
\hline Error & 13803.511 & 171 & 80.722 & \\
\hline Total & 1604525.000 & 179 & & \\
\hline
\end{tabular}

With respect to interaction of variables, data obtained indicate that there was no; significant experience by discipline interaction, discipline by qualification interaction. Statistically significant interaction of experience by qualification was found. To determine the nature of interaction (ordinal or disordinal) established between these two variables (experience and qualification), the group means were examined and depicted graphically for more visual impact. Ordinality and disordinality, according to Glass and Stanley (1970) are properties of graphs. A choice can exist between placing any of the variables on the abscissa while graphing the interaction. The same cell means can give an ordinal interaction when experience is placed on the abscissa and a disordinal interaction when qualification is placed on the abscissa. The reason for graphing significant interaction effects is to determine whether a single statement can be made about the status of each of the variables without referring to any of the levels of the variable.

When experience was placed on the abscissa (see Figure 1) a disordinal interaction was found. Experienced non-qualified teacher educators were more inclined to constructivism in conception of teaching and learning than their qualified counterparts. It was also observed that inexperienced, qualified teacher educators had conception of teaching and learning more inclined to constructivism than their counterparts who are not qualified. By implication, it is not meaningful to make a single statement about experienced and inexperienced teacher educators without reference to their levels of qualification.

There was also disordinal interaction (Figure 2) when qualification was placed on the abscissa. Qualified inexperienced teacher educators had conception of teaching and learning closer to constructivism than their experienced counterparts. But experienced nonqualified teacher educators had conception of teaching and learning closer to constructivism than their inexperienced counterparts though with very little value. By implication also, it is not meaningful to make a single statement about qualified and nonqualified teacher educators without reference to their levels of experience. 
Igwebuike, T. B., Okandeji, C. O., \& Ekwevugbe, A. O.

\section{Table 3}

Mean scores on conceptions by experienced and qualified teacher educators for plotting graphs of interaction

\begin{tabular}{llcc}
\hline & & \multicolumn{2}{c}{ Qualification } \\
& & Qualified & Non-qualified \\
\hline \multirow{2}{*}{ Experience } & Experience & 91.63 & 93.62 \\
\cline { 2 - 4 } & Inexperienced & 98.67 & 93.29 \\
\hline
\end{tabular}

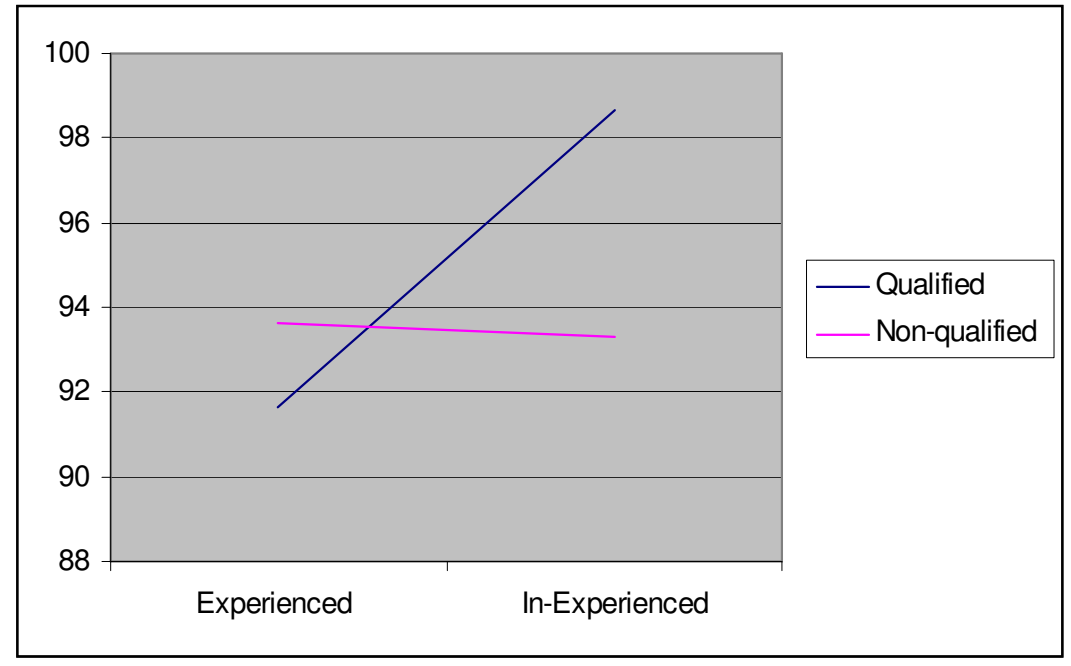

Figure 1: Interaction of qualification and experience (with experience on the abscissa)

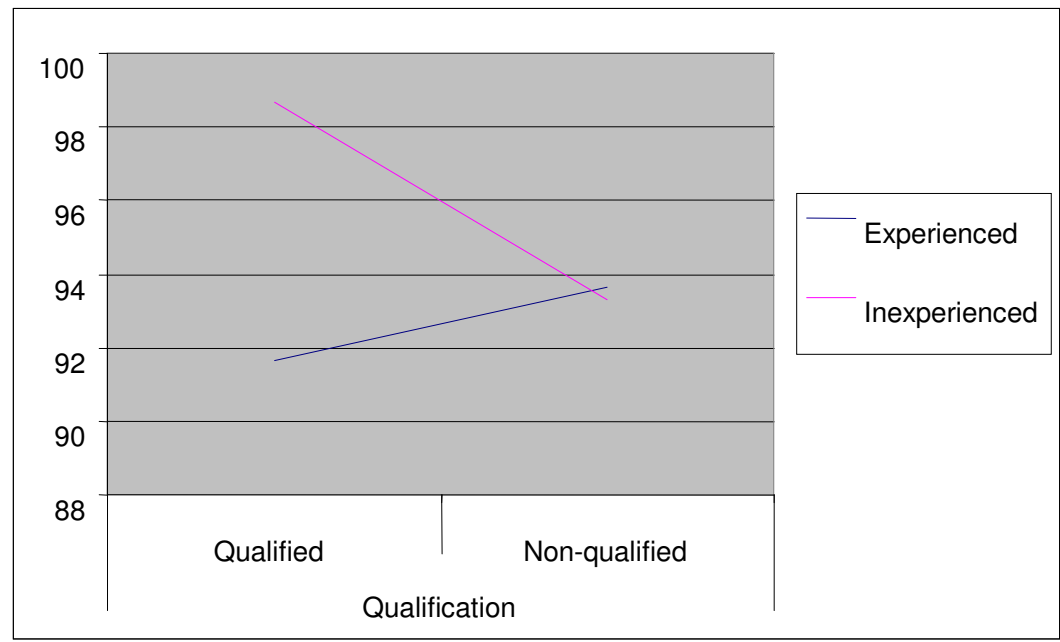

Figure 2: Interaction of qualification and experience (with qualification on the abscissa)

\section{Discussion}

A major hypothesis tested in this study was whether the proportion of teacher educators in Delta State Colleges of Education that had constructivist conception of teaching and learning would be significantly greater than 0.5. Data obtained from this study indicated that the proportion is significantly less than 0.5 . This means that majority of the teacher educators have traditionalist conception of teaching and learning. This result is shocking. This is largely because contemporary research on cognitive and affective learning outcomes has provided several strands of research evidence which converge to show support for the use of constructivist instructional strategy (Trumper, 1990, 1991; Bajah \& Asim, 2000; Igwebuike, 2000, 2010; Chang \& Bell, 2002; 
Teacher educators' conception of teaching and learning in teacher education institutions

Ndioho, 2008). This has led to the advocacy for the use of instructional strategies premised on constructivist epistemology as well as measurement of constructivist classroom environments (Smerdan \& Burkam, 1999; Aldridge, Fraser, \& Tailor, 2000; Boddy, Watson, \& Aibusson, 2003; Igwebuike \& Okandeji, 2009; Igwebuike, 2011). Majority of the teacher educators that prepare pre-service teachers for teaching, this study has shown, have traditionalist conception of teaching and learning. This finding can speculatively be explained by the fact that the traditionalist approach to teaching and learning is a simplified approach (Igwebuike, 1995; Igwebuike \& Okandeji, 2009), and can be used to absorb the phenomenal population explosion in various institutions of higher learning which is not matched with provision of equipment, facilities and materials for teaching.

With respect to the second hypothesis which states that there is no significant difference in conception of teaching and learning by qualified and non-qualified teacher educators, data obtained in this study support the retention of the hypothesis $\left[\mathrm{F}_{(1,178)}=1.914, p>0.05\right]$. It was expected that the qualified teacher educators would have developed constructivist concept of teaching and learning during their sojourn in teacher education institutions. But they could not because, as confirmed by this study, teacher educators themselves have traditionalist conception. This observation provides a plausible explanation to the finding of this study with respect to the second hypothesis.

The third hypothesis states that there is no significant difference in conceptions of teaching and learning between teacher educators in science and technology and their counterparts in arts and social sciences. This hypothesis was not rejected because no significant difference was found between the two groups $\left[F_{(1,178)}=0.576\right.$, $p>0.05]$. This result is supported by the finding, from Igwebuike's (1997) study, that there was no significant difference in views about epistemology and classroom practices held by science and non-science teacher education students. It was expected that teacher educators in science and technology would differ in their conception of teaching and learning from their counterparts in arts and social science because the benefits of science and technology are increasingly making it look as humane as constructivist instructional strategy which has been projected as learner-centered strategy (Igwebuike, 2011). This result can be explained by the fact that irrespective of the discipline the teacher educators were taught the same way by teachers who had a tenacious hold on the traditionalist conception. Many teachers teach the way they were taught and hold somewhat similar beliefs with their teachers. Besides, despite the acknowledged efficacy of constructivist instructional strategy, teachers, as well as teacher educators, have not been challenged to reconsider their conceptions of teaching and learning.

The fourth, and the last, hypothesis states that there is no significant difference in conceptions of teaching and learning between experienced and inexperienced teacher educators. Data obtained indicated that the hypothesis should be rejected $\left[\mathrm{F}_{(1,178)}=4.55, p<0.05\right]$. This means that the inexperienced teacher educators with higher group mean had conception of teaching and learning that is more inclined to constructivist precepts. It was expected that experienced teacher educators would have conceptions that are more inclined to constructivist precepts. This is because experience is believed to improve performance and conceptions. But this study has provided data which do not support the expectation. This result can be explained by the fact that experienced teacher educators hold on tenaciously to traditionalist conceptions of teaching and learning. They are therefore impervious to contemporary approaches to teaching and learning. Attempts to improve interactions in classrooms by practicing teachers are, consequently, based on mere pious hopes and professional chauvinism rather than on reality. Based on this misplaced belief, Igwebuike and Okandeji (2009) called for a revamping of teacher education programs and constant update of knowledge by teacher educators in Nigeria.

\section{Conclusions}

The findings of this study support the conclusion that majority of the teacher educators have traditionalist/transmissive conceptions of teaching and learning. Evidence that inexperienced teacher educators have conceptions of teaching and learning more inclined to the contemporary/constructivist model than their experienced counterparts is also provided by the findings. 


\subsection{Implications}

From the foregoing, an implication of these findings is that teacher educators in Colleges of Education in Delta State, Nigeria would need to be aware of the weaknesses of their conceptions of teaching and learning. They should be assisted to be open-minded to contemporary approaches to organizing interaction patterns in their teacher education programs. The National Policy on Education (Federal Republic of Nigeria 2004) states, "No education system may rise above the quality of its teachers" (p. 39). This supports the trepidation expressed in this paper. Seminars, conferences and workshops within which teacher educators views on teaching and learning can be challenged, should be organized for them. Ways of assisting them to reduce their tenacious hold on the traditionalist conception should be explored.

However, it must be mentioned that the fragmentary nature of data presented in this study can only lead to suggestions rather than conclusions and this is why the implication drawn from it is restricted to the population used in this study. More studies are solicited, in this area, to validate or otherwise the findings of this study and to improve on the generalizability of the findings especially now that there is quest for ways of making teaching to be learner-centered.

Despite the fact that we encourage cautious interpretation and application of the conclusions of this study, we hope that this study has generated curiosity adequate enough to simulate further studies of this phenomenon.

\section{References:}

Aldridge, J. M., Fraser, B. J., \& Taylor, P. C. (2000). Constructivist learning environments in a cross-national study in Taiwan and Australia. International Journal of Science Education, 22, 33-35. <http://dx.doi.org/10.1080/095006900289994>

Asim, A. E. (1998). An evaluation of relative effectiveness of two interactive approaches based on the constructivist perspective for teaching primary science. Unpublished Doctoral dissertation, University of Ibadan, Nigeria.

Bajah, S. T., \& Asim, A. E. (2000). Constructivism and science learning: Experimental evidence in a Nigerian setting. Journal of the World Council for Curriculum \& Instruction Nigeria Chapter, 3(1), 106-114.

Boddy, N., Watson, K., \& Aibusson, P. (2003). A trial of the five Es: a referent model for constructivist teaching and learning. Research in Science Education, 33, 27-42. <http://dx.doi.org/10.1023/A:1023606425452>

Chan, K. W. (2004). Pre-service teachers' epistemological beliefs and conceptions about teaching and learning: Cultural implications for research in teacher education. Australian Journal of Teacher Education, 29, 2-13.

Chan, K. W. (2007). Hong Kong teacher education students' epistemological beliefs and their relations with conceptions of learning and learning strategies. The Asia-Pacific Education Researcher, 16, 199-214. <http://dx.doi.org/10.1023/A:1015054804515>

Chang, W., \& Bell, B. (2002). Making content easier or adding more challenge in year one university physics. Research in Science Education, 32(1), 81-96.

Entwistle, N., Skinner, D., Entwistle, D., \& Orr, S. (2000). Conceptions and beliefs about "Good Teaching": An integration of contrasting research areas. Higher Education Research and Development. 19, 5-26. $<$ http://dx.doi.org/10.1080/07294360050020444>

Fang, Z. (1996). A review of research on teacher beliefs and practices. Educational Research, 38, 47-65. $<$ http://dx.doi.org/10.1080/0013188960380104>

Federal Republic of Nigeria. (2004). National policy on eEducation. Abuja: Ministry of Information.

Igwebuike, T. B. (1995). Curriculum planning and development: Principles and practice. Warri, Nigeria: COEWA Publishers.

Igwebuike, T. B. (1997). NCE educatees' views on epistemology and classroom practices. The Nigerian Teacher Today: A Journal of Teacher Education. 9(2), 69-77.

Igwebuike, T. B. (2000). Effects of constructivist instructional strategy on students' achievement in integrated 
Teacher educators' conception of teaching and learning in teacher education institutions

science. Unpublished Doctoral dissertation, University of Benin, Benin-City, Nigeria.

Igwebuike, T. B. (2009). Innovative science skills and Vision 20-2020: Some thoughts on science teacher education. Lead paper presented at the School of Science, College of Education, Warri, National Conference on Vision 20-2020, 15-17 June.

Igwebuike, T. B. (2011). Some global issues in educational research: A new research agenda. A Resource Paper presented at a seminar organized by School of Arts and Social Sciences, College of Education, Warri, Nigeria.

Igwebuike, T. B., \& Okandeji, C. O. (2009). Traditional and contemporary conceptions of teaching: Implications for revamping teacher education programs in Nigeria for Vision 20-2020. Text of paper presented at the 2009 Annual National Conference of the School of Education, College of Education, Warri -Nigeria, 17-19 June.

Joe, I. A. (2005). Foundational statistics for education and behavioral sciences. Ibadan, Nigeria: Kraft Books Limited.

Kane, R.; Sandretto, S., \& Heath, C. (2002). Telling half the story: A critical review of research on the teaching beliefs and practices of university academics. Review of Educational Research, 72, 177-227. <http://dx.doi.org/10.3102/00346543072002177>

Ndioho, O. (2007). Effect of constructivist-based instructional model on senior secondary students' achievement in biology. In U. Nzewi (Ed.) Science technology and maths education for sustainable development (98-101). Ibadan, Nigeria: Heinemann Educational Books Nigeria.

Pope, M., \& Scott, E. (1983). Teachers' epistemology and practice. Paper presented at the 1st International ISATT Symposium at Tilburg University, the Netherlands.

Samuelowicz, K., \& Bain, J. (2001). Revisiting academics' beliefs about teaching and learning. Higher Education, 41, 299-325. <http://dx.doi.org/10.1023/A:1004130031247>

Segal, S. (1998). The role of contingency and tension in the relationship between theory and practice in the classroom. Journal of Curriculum Studies, 30, 199-206. <http://dx.doi.org/10.1080/002202798183701>

Smerdan, B. A., \& Burkam, D. T. (1999). Access to constructivist and didactic teaching: who gets it? Where is it practiced? Teachers College Record, 101(1), 5-9. <http://dx.doi.org/10.1111/0161-4681.00027>

Teo, T., \& Chai, C. S. (2008). Confirmatory factor analysis of the conception for teaching and learning questionnaire (CTLO). The Asia-Pacific Education Researcher, 17(2): 215-224.

<http://dx.doi.org/10.3860/taper.v17i2.733>

Trumper, R. (1990). Being constructive: An alternative approach to the teaching of energy concept. Part I. International Journal of Science Education, 12(4), 411-436. <http://dx.doi.org/10.1080/0950069900120402>

Trumper, R. (1991). Being constructive: An alternative approach to the teaching of energy concept. Part II. International Journal of Science Education, 13(2), 411-436.

Young, R. E. (1981). Study of teacher epistemologies. Australian Journal of Education, 25(2), 194-208. 
Igwebuike, T. B., Okandeji, C. O., \& Ekwevugbe, A. O. 